\title{
Unlocking carceral atmospheres: designing visual/material encounters at the prison museum
}

\section{The barber's chair}

The cell was empty but for the barber's chair. The chair was unoccupied and the cell oppressively grey. The only light in the room, barely touching the walls, came from a small window, high up. The light itself dampened from the dismal day outside, the rain and the overcast sky. And in this room it made that chair look frightening; a sole remnant of the past that surely had held horrors. I can't explain it, put my finger on it. It looked too macabre to be innocent. It sent a chill down my spine as I imagined someone sat in it - head-tilted, hair-cut, beard-shaved. I felt odd, like some realism of the past had collided with my present. I had to leave. (Diary excerpt, Eastern State Penitentiary, April 2013)

We begin this paper with the stubbornly-material and visually-evocative image of the barber's chair in the Eastern State Penitentiary, Philadelphia, PA, USA (see Figure 1.). The chair is located in a single cell: one of many along a decaying, crumbling corridor that radiates from the central rotunda of the prison. Eastern State was designed in the late $19^{\text {th }}$ Century, during a period in which society sought to redress the treatment and fate of incarcerated individuals from a process of punishment to rehabilitation. This 'civilisation' of punishment and care of the prisoner was built into the architecture of Eastern State, where individual cells and self-discipline (achieved through a panoptical design) would encourage reflection and penitence (see Johnston et al., 1994; Magnani, 1990). Although this project largely failed and Eastern State shifted to a more punitive ethos in the remainder of its 142- 
year history, the site remains a material symbol and visual reminder of particular moments of American carceral history. Indeed, in 1994, the former prison became a museum, actively recalling its carceral past through the introduction of timed tours (Eastern State Penitentiary, 2014).

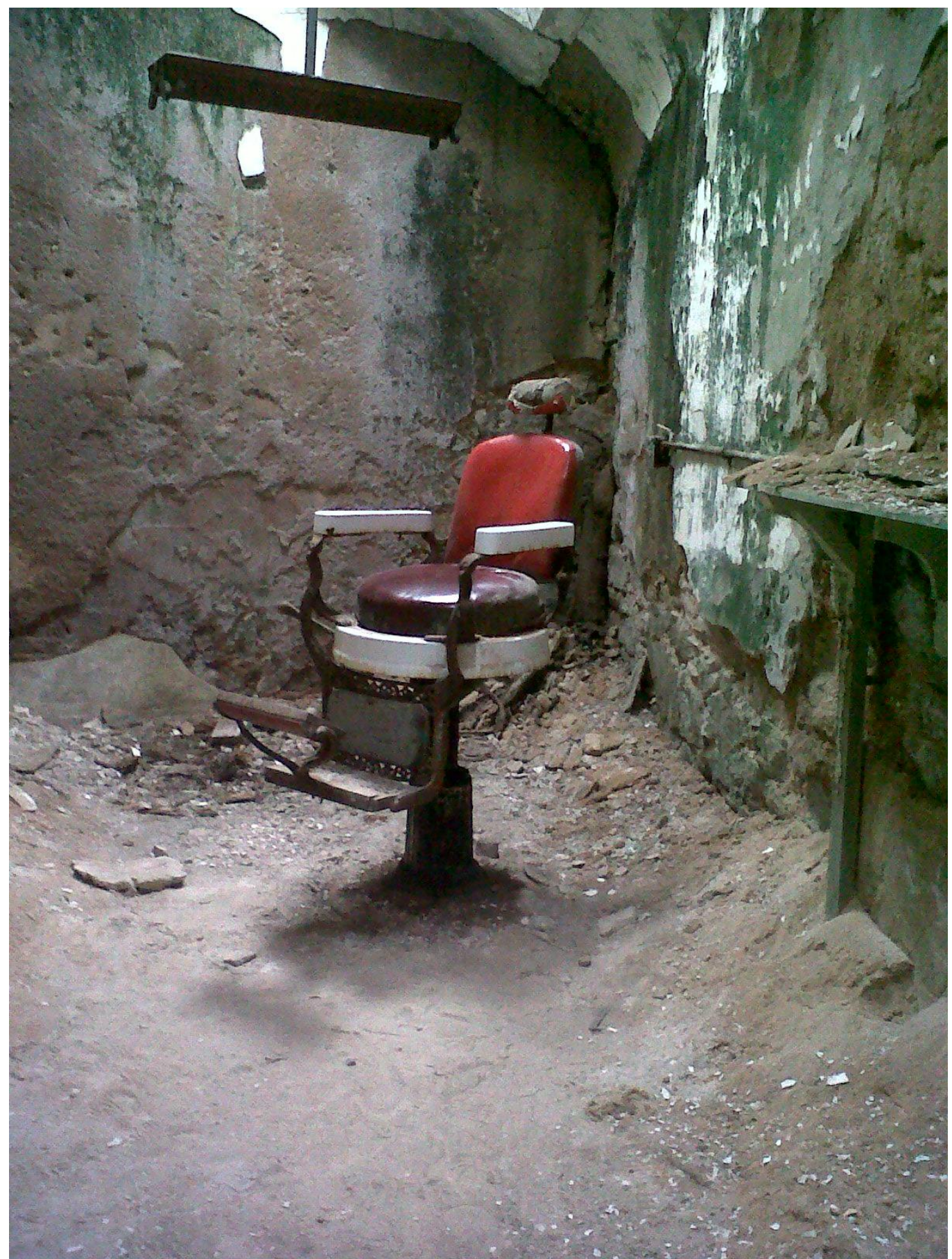

Figure 1. The Barber's Chair. Eastern State Penitentiary, Philadelphia. Source: Author's collection. 
The first criminological museums emerged in the $19^{\text {th }}$ century as teaching institutions inspired by positivist theories (Morrison 2004). Objects and pictures were displayed that showcased theories about crime and its perpetrators. For example, amongst artefacts such as crime scene photographs, criminal disguises and murder weapons, visitors to the Palazzo delle Belle Arti in Rome in the autumn of 1885 became witness to the unusual spectacle of

no less than five completely conserved heads ... and that of the infamous bandit Giona La Gala, which was there in the exhibition of the Genoa penitentiary, complete with his brain, tattoos, and gall bladder stones found during the autopsy (Broeckmann 1995, 3).

On the one hand, these early museums used material/visual ${ }^{1}$ cues to educate visitors of the horrors of crime. On the other, they also introduced viewers to the raw realities of criminal activity and the thrill of dangerous people. In recent years, penal tourism has grown in popularity as sites of 'negative sight-seeing', tragedy, grief and horror, have saturated the commercial market of visitor attractions (MacCannell, 1999; Strange and Kempa, 2003; Walby and Piche, 2011: 452). Much penal tourism takes shape through the attraction of the prison museum (although there are exceptions_- prison tourism can include visits to prisonerrun restaurants and residential stays at prison hotels, see Turner 2013). The prison museum, in many respects, functions much like any museum-communicating knowledge of the past, in the present (see Crang, 2003; Geoghegan, 2010; Hooper-Greenhill, 1992; Macdonald, 2007). However, the prison museum also represents a past that is dislocated for visitors, both spatially and temporally. Indeed, the penal museum not only moves the visitor through various moments of carceral history, it likewise takes them to a place they are unlikely to ever visit in 'normal' everyday life: the prison. Indeed, many of these museums are located in 
former prisons themselves (the museums of Alcatraz and Robben Island are two infamous examples). As such, curators are able to utilise the stark material and visual remnants that haunt these disused buildings. This brings an uncanny sense of realism and 'presence' to the histories that are told in the present (see Bagnell, 2003; Bjerregaard, 2014). Eastern State is no exception. The penitentiary museum recalls a history manifested, and emergent from the very greying, crumbling, oppressive walls of the building it is located within.

Yet, to return to the barber's chair, history is not simply in the visual/material canvas of the site amongst the bricks, mortar and remaining objects. Certainly these features and items have the capacity to unlock histories; to tell tales of times, places and people in the past. But histories require curation. Meaning has to be brought to bear on what is displayed (see Crang, 1994). Like all museums, Eastern State is carefully and meticulously curated and designed (see Bruggeman, 2012). The uncared-for and dilapidated chair is no less a forgotten item, than one left in a state of arrested decay (DeSilvey, 2006) to elicit a visually evocative, haunting image for those viewing it from the cell door. The site, in its disused state provides the visitor not with a sense of a working prison in the past, but with a decrepit, ruinous present/ce (Bjerregaard, 2014). In doing so, the museum does more than simply display artefacts and tell stories through cabinets of curiosities, like a conventional museum. It is a museum that makes meaning through the decision to leave paint peeling, walls crumbing and chairs degrading. It is a museum that uses its highly visual, stubbornly-material architecture to evoke politically-charged experiences of the past for those who visit. To date, much literature that has explored the workings of museum spaces has attended to specific elements of museum curatorship such as the use of visual displays, material objects, sensory engagements and embodied performance (although see Waterton and Dittmer, 2014, who consider the museum as an 'assemblage' of such elements). But what these studies lack is a consideration of the altogether more pervasive, intangible and complex sensations designed, 
engineered, co-constituted and also arising unexpectedly from museums housed in sites of their former use. Here, we contend, an examination of 'atmospheres' is particularly productive.

Accordingly, in this paper we 'unlock' the atmospheres emergent from former prisons that are now museums. In doing so, we focus on the production and consumption of museumscapes and the use of visual/material cues for informing visitors about the past, which elicit and construct 'atmospheres' that help build understandings of these sites and their histories. As such, we examine what 'carceral' atmospheres do and how they shape public imaginaries about the ordinarily inaccessible space of the prison. To do so, we focus on two sites: the already introduced Eastern State Penitentiary in Philadelphia, PA, USA and the Galleries of Justice, Nottingham, UK. We begin by reviewing studies that have investigated the design and consumption of museum space, before turning attention to the newly emerging understandings of atmosphere and atmospherics, shaping the social sciences. We then 'go to prison', turning to visitor recollections, curatorial insights and our own auto-ethnographic engagements with designed museum spaces, to unlock carceral atmospheres.

\section{Making museums}

Museums, as collections of materials, objects and narratives transformed into carefully curated displays and exhibitions can be traced back to the 'cabinets of curiosities, (and) study collections $\ldots$ belonging to royalty and wealthy families' in the $17^{\text {th }}$ century (Geoghegan, 2010: 1462). However, the project of preserving and displaying history more systematically began in the $1800 \mathrm{~s}$, as state powers sought to communicate 'authoritative knowledge' about the world to the wider public (Crang, 2003: 259). Some museums work to project national stories, whilst others represent regional or local histories, or the histories relating to particular peoples, subjects and themes. The pervasiveness of museums (see Geoghegan, 2010: 1463) 
has called into being the discipline of 'museology' - the critical exploration of how such sites function in their role as containers and communicators of the past. This project is unsurprisingly interdisciplinary in focus, bringing anthropologists, architects, sociologists, and geographers into touch (see Macdonald, 2007: 149). However, key to such studies has been an interrogation of how museums function (see Karp and Levine, 1990). Museums do not innocently represent the past; they do so in ways that are imbued with power. Museums are said to communicate particular political standpoints and 'official' histories, silencing some events, people and pasts in the process (Crang, 1994; 2003). More recently, however, this critical shift has motioned scholars away from the museum curators as 'all-powerful' experts in narrating histories, to instead, an appreciation of the agency of the visitor in mutually making meaning through active engagement with the museum space (Macdonald, 2007: 150).

This emphasis on how museums function has turned attention to the design and curation of museum exhibitions by museum experts and an ever-more-active body of visitors who engage with displays through multiple senses (touch, smell, sound) and via virtual techniques (see Howes, 2014). In taking on such a task, academics have considered the role of materiality in museum design and the narration of history (see Hoskins, 2004; 2007); the place of performance in presenting the past (see Johnson, 1999a, 1999b); the importance of museum space and the routing of visitors (see Geoghegan, 2010); the role of shared engagement and sociality in experience (Macdonald, 2007); and new virtual, audio and sensory technologies as mediums of bringing the present into touch with the past (Ciofi and Bannon, 2007; Howes, 2014). However, each of these dimensions in museum design is taken as a discrete method of engineering historical narratives for visitors (and as ways visitors can themselves author narratives of the past). What is missing in these accounts is how these elements - and relations between them-might cohere or assemble into something far less 
obvious, but far more pervasive: atmospheres (see also Waterton and Dittmer, 2014). Indeed, the aforementioned barber's chair is a visually-stimulating, performative object (visitors are allowed to touch the chair, and sit in it). But what is engineered-what is provoked-on encountering the chair cannot be reduced to how it looks; its brute materiality; the performances it becomes embroiled within; or its spatial context alone. It is something else. It is the thing you cannot put your finger on. It is the ephemeral sense that coalesces around and emerges from those more visual, tangible and/or experiential components. As Bjerregaard notes — drawing on Böhme's understanding of 'atmosphere' - there is

the capacity of the museum to generate a kind of embracing experience, wrapping the visitor in an atmosphere ...this atmosphere also seems to dissolve the individual objects at display allowing them to become a part of the general experience of space (2014: 2, original emphasis).

Whilst we do not concur that objects 'dissolve' into space (this notion reducing the importance of the very evocative affects and capacities of 'brute' materiality), we, like Bjerregaard (2014), contend that discussions of how histories are produced, consumed, understood and 'felt' are incomplete. This is because visuality, materiality, performance, sociality, technology and so on, are not singular categories that are employed and engaged with. They come to produce-in assemblage with bodies, in time and space-something larger and more encompassing: atmospheres. As Waterton and Dittmer have recently argued - in relation to the Australian War Memorial-a series of elements that appear as 'background noise' in museums (lighting, sounds, and visitor engagements) cohere together (and come apart) to "do greatly productive work in terms of engineering atmospheres" (2014: 122). Indeed, when reflecting on a visit to the Galleries of Justice tourists there spoke of 
'atmosphere' - the lingering sense of something surrounding them that is unique to these spaces:

Towards the end of the tour we wandered around freely and soaked up the atmosphere of the venue. It was quite eerie - especially when I entered a dark cell and my son jumped out on me! (Julie6468, TripAdvisor review of visit to Galleries of Justice Feb 2014)

We found this attraction excellent, from the guided tour which was very informative to the visit to the cells which was very eerie and atmospheric. It's very much worth a visit if in Nottingham. (chrisworthington48, Trip Advisor review of visit to Galleries of Justice Mar 2013)

But how are these 'carceral' atmospheres described? How can we better understand them and how they emerge, are designed, engineered and co-constituted between curators and visitors to aid understanding of penal histories? In his recent work charting the geopolitics, mobilities and materialities of air, Peter Adey has explored the workings of 'atmosphere' (2013). For Adey, atmosphere refers to a thoroughly material, elemental state. The atmosphere is an atomic, particular and molecular form that surrounds our every move and also one that permeates the body through the air we breathe in and exhale. An atmosphere, then, is something tangible - it has matter and force — it can be consumed, physically felt, and moved through, in spite of its apparent intangibility. Yet atmosphere is also more than this. It is metaphoric as well as actual.

In his discussion of the 1897 Andrée balloon flight expedition, McCormack encapsulates this dual way of attending to atmosphere through 'an account of the materiality 
of atmospheric space that aims to move between two ways in which the term is registered and understood' (2008: 413). First, McCormack notes, atmosphere is 'meteorological'. It is a 'turbulent zone of gaseous matter surrounding the earth and the lower reaches of which human and non-human life moves'. Second, atmosphere is 'affective' in respect of being a 'distributed' medium that 'registers in and through sensing bodies' (2008: 413). An atmosphere then, is not simply the air itself, but something held in the air; an intangible, ephemeral state that elicits 'affects' on the body-subject as a result of what Adey calls conditions (2013). Here affect refers to 'a transpersonal capacity which a body has to be affected (through an affection) and to affect (as the result of modifications)' (Anderson, 2006: 735). In other words, affects do not reside in bodies but in the space between. They are the emergent haptical and emotional responses that arise when bodies come into touch with the conditions of an atmosphere-its character and qualities (produced through its aerostatic dimensions and metaphorical dimensions). In thinking of atmospheres in this way (see also Edensor and Sumartojo, this issue), we contend that being alert to the elusive, intangible, felt, aspects of carceral space that seep from, and are designed, engineered and co-constituted around material and visual components of the museum, opens up a more enlivened and 'full' sense of space: the atmospheres that surround, shape us and are shaped by us. Accordingly, in what follows, we explore the atmospheres of two prison museums. Unlocking what we call 'carceral atmospheres' is vital to analysing penal museums to fully understand how they might be designed but also experienced and felt by visitors who enter these ordinarily inaccessible sites.

\section{Accessing the prison museum}

In order to experience and interrogate the distinctive atmospheres engineered and emergent within the space of the prisons, fieldwork consisted primarily of an auto-ethnographic 
approach where our participation in the research context co-created the very atmospheres we explored (see Butz and Besio 2009). By engaging with the prison museum directly-their carefully designed layouts, articulated histories, material displays and planned performances-we were able to access and consume the managed and engineered atmospheres (co)produced by the prison museum curators and tourists as users of the space. Following Crang and Cook (2007: 6) such a method was not selected as a simple means of 'reading' a space, landscape or event to identify a socio-cultural construction of past. Rather it was a dynamic, reflexive and considered way of 'assaying' the past and interrogating it in the present (Garrett, 2011). Moreover, we were able to embody a unique positionality—as researcher, tourist, and performative 'prisoner'. Such an approach has been central to gaining deeper understandings of how museums function (see Crang, 2003; Macdonald, 2007).

Fieldwork at the Galleries of Justice entailed multiple site visits with the authors taking part in a variety of scheduled tours as well independent navigation of the museum exhibits. Alongside this active participation, conversations were held with curatorial staff and tour guides. At the Eastern State Penitentiary, fieldwork included independent navigation of the site as well as the undertaking of the optional audio tour. Analysis of promotional materials and guidebooks (both in print and online) was also undertaken for each museum. This was in conjunction with collating 652 online consumer reviews of the 'attractions'. We analysed user comments posted during designated time frame of the research (January 2012 to March 2014) in order to accumulate the most current opinions and correlate with the autoethnographic observations made at the sites (therefore not referring to defunct exhibitions). Whilst the use of such data is not unproblematic (Paechter, 2013), we follow Langer and Beckman's assertion (2005) that open-access websites are public documents which may be used for research purposes on the basis that those posting information have consented to its use. These postings provided a rich and informative insight into tourist engagements with the 
penal museums in question. The museums selected for study differ in their design, history and contemporary utilisation. The alternative staging and production (MacCannell, 1973) of penal histories and regimes by these museums made them suitable for a comparative study of the relations between prison histories and contemporary understanding-the (co)production (between museum and tourist) of carceral atmospheres.

There has been a legislative or court building at the location where the Galleries of Justice museum currently stands since 600AD. The earliest record states that the site was used for a court as early as 1375, and as a prison from 1449, though it is possible it functioned as both before these dates too. Until the mid-19th century the Galleries contained courts, prison wings and a public hanging yard. In 1878, due to appalling conditions, the prison was closed. The Galleries continued to be used as a court until 1991. In 1993 the Lace Market Heritage Trust took ownership of the Galleries, transforming it into a museum, which opened two years later in 1995 (Baker, 2014). The museum itself is one which tells multiple histories, of both a specific carceral past relating to the former court and prison on site, and to a national history of crime and punishment in the UK. Whilst the Galleries have been an overlapping location of justice and imprisonment for centuries, the Eastern State Penitentiary is a very different prison site. Designed by John Haviland and opened in 1829, the prison was conceived with an ethos of separate confinement in mind. This was based on the belief that silence and solitude would encourage rehabilitation as inmates reflected on their wrong-doing (see Johnston et al., 1994). However, it is widely acknowledged that far from a space of peaceful confinement, Eastern State was often a site of terror with disciplinary regimes enacted on prisoners such as the two-week confinement to 'the hole' (which can still be visited today). By 1913 this project of solitary imprisonment was abandoned as the prison suffered overcrowding. In the last of the developments to take place in 1956, 'Death Row' - a particular cellblock of electronic confinement for prisoners awaiting execution-was added 
to the prison (see histories by Johnston et al., 1994; Magnani, 1990). The prison closed in 1971. In 1994 the site began its transformation into a prison museum as the Pennsylvania Prison Society opened the Penitentiary for guided tours. A non-profit corporation, Eastern State Penitentiary Historic Site, Inc., took over the agreement 2001 operating the site since, as the museum it is today. In what follows we unlock a discussion of the carceral atmospheres that are designed, engineered, co-constituted and seep unexpectedly from these former prison sites. Here we focus on how visual/material components - and the performative elements of museum curatorship that take cue from them-comprise emergent atmospheres in these former carceral spaces.

\section{Curating atmospheres: visual/material cues in the prison museum}

At both sites the stark visual dominance and striking material architecture is utilised by curators to present prison histories. In this way, visuality and materiality are acted upon to generate atmospheres that linger in and seep from the bricks and mortar, the empty cells, the walkways and the exercise yards as visitors engage with these past, penal spaces. The buildings possess (as Anderson notes, 2009: 78) atmospheres of their pasts elicited as visitors in the present come into contact with the visual/material forms that have history imprinted upon them. Architecture, whether left to degrade or renovated, serves to create conditions for specific atmospheres to be engineered (see Adey, 2008) by those designing museum space.

At Eastern State relatively little has been touched in transforming the site from prison to prison-museum. As the guidebook states 'the prison stands today in ruin, a haunting world of crumbling cellblocks and a surprising, eerie beauty' (Eastern State Penitentiary, 2013: n.p.). The building, as seen in Figure 2, is specifically left in a state of disused decay. As one visitor noted, 
The grounds are filled with the abandoned corridors of the prison, with most cell doors sealed shut, while others left slightly agape, with an eerie blackness that stares back at you. (tempusfugit83, Trip Advisor review of visit to Eastern State Penitentiary Apr 2013)

Eastern State portrays a bleak carceral experience, but through carefully curated ruination. As the visitor describes, doors deliberately left slightly ajar or locked tight shut, create unsettling atmospheres of what is not seen (as well as what is visible); evoking hidden horrors of carceral life behind closed doors. These are sensory atmospheres hinged around the in/visible and material, but also emergent from these features (Waterton and Dittmer, 2014). They are senses of transfixion and also discomfort at the unfamiliar. As Edensor has noted, the ruinand its disorderly nature compared to the regulated aesthetics of urban architecture — provides opportunity for a more sensitized spatial engagement. The 'unfamiliarity' of ruinous space means the body is "reactive to the effusion of sensory affordances" and "actively engages with the things it beholds" (2007: 229). Although Eastern State is an 'organized' ruin, as a former prison (a space few will have encountered), the atmospheres elicit senses that would be unusual in everyday space. Here the door ajar - the darkness within - makes the heartbeat rise and the palms clammy in anxious trepidation of the unknown within. However, it is often these atmospheric sensations that draw visitors in to such sites/sights. As another visitor describes,

When you pull up and are positioned in front of this castle-like abnormality; you already get the eerie sense that you're about to travel centuries back in time ... to a place where you are not welcome; much less want to be. The funny thing is, like a tractor beam, you are drawn in and any attempt to make a sudden change in plans is 
futile ... Right off the bat you are feeling dwarfed by the massive walls and the cell blocks all have a chill that has your hair stand on end (and this is just as you stand in the doorways). Even knowing the history cannot prepare you for the flood of emotional anguish that you can be bombarded with in certain areas of this 18th century behemoth. (SamHaine, Trip Advisor review of visit to Eastern State Penitentiary Sep 2012)

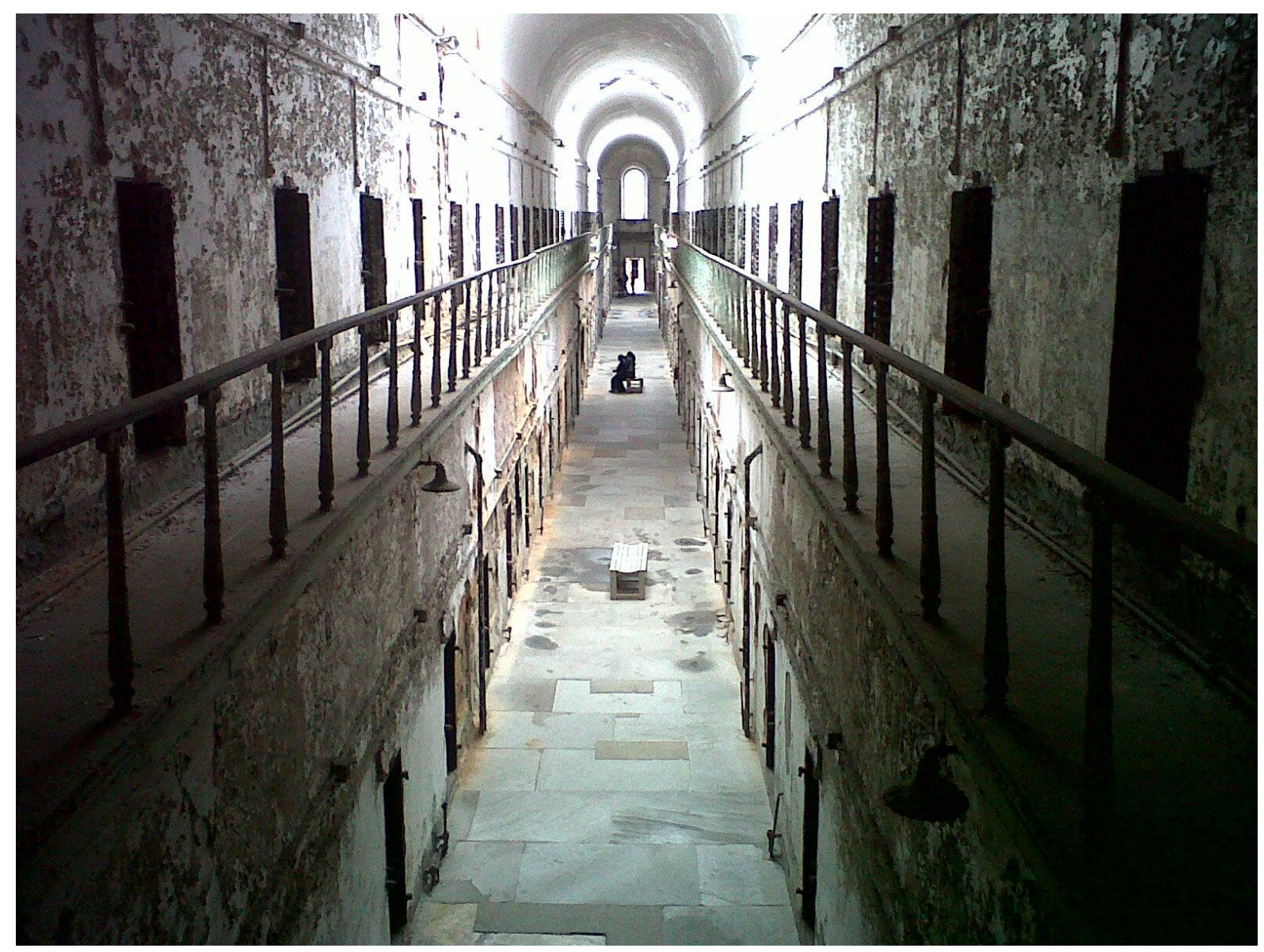

Figure 2. A decaying prison wing at Eastern State Penitentiary, USA. Source: Author's collection. 
The remains of the structure suggest only an ephemeral or fleeting indication of what has gone before, evoking an inarticulate yet affective influence upon those who experience it. As the visitor described: 'even knowing the history cannot prepare you'. As Edensor explains, although a space 'endlessly' moves on, it still 'leaves behind traces of its previous form, social life, inhabitants, politics, ways of thinking and being, and modes of experience' (Edensor, 2008: 315). The ruinous remains of Eastern State and decisions as to how to manage the architecture (affectively leaving it to decay, see DeSilvey, 2006) helps generate the atmosphere of the place: the ghostly, cold, uncanny sense of how we might envision carceral life. Moreover, as Avery Gordon (2008) notes, forgotten 'others' often hang as ghostly hauntings amidst the materiality of place, shaping the very meaning and atmosphere that develops (see Mayerfield-Bell, 1997: 815). Certainly these traces of incarcerated others are etched visually in the materiality of the place itself. As the same visitor noted,

The stories of ghosts are what draws most to this place and after understanding the torture and the lunacy... it is the stories of ghosts that keep you wandering the neverending halls and cell blocks. When you have walked it all; you want more... you want to see all the things that are hidden. You leave this place with a new appreciation for life, those you love, American history, the new reformed prison system or, simply, a need to come back. (SamHaine, Trip Advisor review of visit to Eastern State Penitentiary Sep 2012)

As the visitor describes, what (and whom) is seen or unseen within the material architecture seems to act as cue for a raft of inquisition, feeling, and engagement with the carceral sphere: an 'appreciation for life', for 'those you love', for 'American history'. Carceral atmospheres, seeping from the visual/material containment of the prison and curatorial decisions, build 
structures of feeling and evoke senses for the visitor that enable them to engage with prison space: its confinement, the loss of liberty inmates experience, the bleak environment.

Graffiti carved into the wall of the Victorian exercise yard at the Galleries of Justice likewise offers an enduring evocation of past atmospheres enlivened in the present. Prisoner S. Clark etched his personal tag into a brick in the exercise yard to show that he, of Sutton in Ashfield, had been condemned to death on 10 March 1881 for 'house braking' (burglary) (see Figure 3.). This is just one example of many other instances of prisoners carving themselves a small memorial — often with whatever tools they could beg or borrow — in order to create an enduring presence for themselves. Like many visitors we saw in the museum, we looked at this etching, touched it, traced our fingertips over the carved message written by a past inmate. As Howes notes, touch creates a "sensation of intimacy with the original creators of objects on display" (2014: 260). At such a moment, an odd temporal enfolding occurs as past and present collide, and the body shivers - our bodies shivered - a cold sensation seeps from the walls and hangs in the air of the yard where the man himself was hanged, evoked from an oddly visual/material engagement with the past. These sensations are inherently hinged upon notions of carceral space. They allude to atmospheres of forced confinement, loss of liberty, desperation and resourcefulness. 


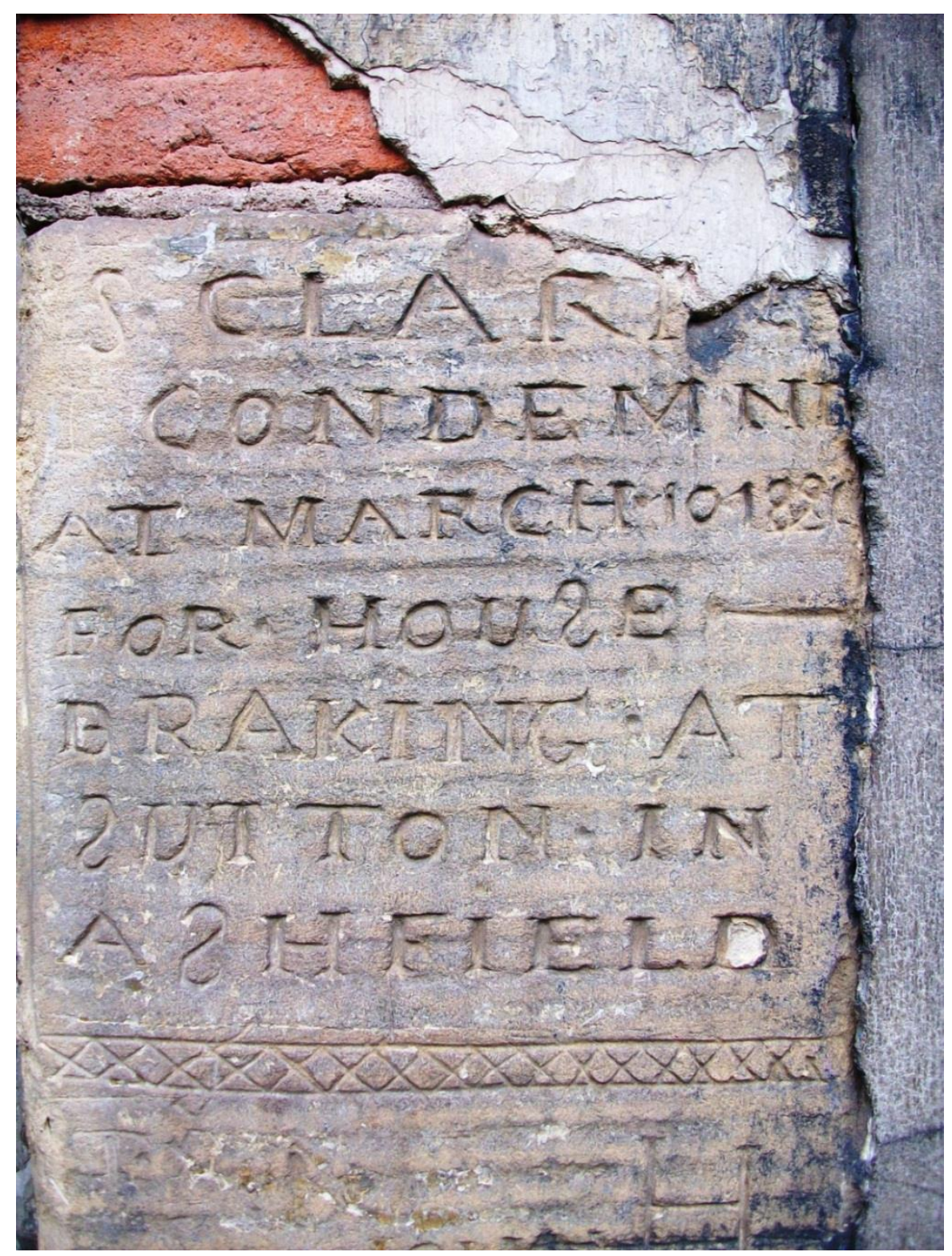

Figure 3. Graffiti carved into the wall of the exercise yard of The Old County Gaol, Galleries of Justice, Nottingham, UK. Source: Author's collection.

\section{Co-creating atmospheres: visual/material performances in the prison museum}

These experiences in the penal museum are not just material and optical though (see Rose and Tolia-Kelly, 2012). Haptical encounters take cue from what is seen and touched. At the Galleries of Justice, performance is an important way in which museums seek to engage their visitors in co-constituting histories (MacDonald, 2007). Such performances are reliant upon the material provenance and architectural form of specific areas of the prison and the visual 
expectations of visitors. For example, the Galleries use costumed interpreters depicting a turnkey and turnkey's wife in the Georgian part of the prison, so that the characters, their clothing, their props and their setting, 'accurately' match one another. Likewise, curators take a visual/material cue from the prison exercise yard, placing a stern-looking Victorian matron at the entrance to this space, (re)presenting the very figure who would have led inmates to disciplined exercise. Such performances are also reliant on visitors embracing different roles in turn contributing to and co-constituting the conditions of the atmospheres generated. As Waterton and Dittmer (2014) posit, visitors are powerful elements in constituting, changing or 'tipping' (to follow Ash, 2013) atmospheres. These visitor performances rest on highly visual techniques that build atmospheric experiences of carceral space; of suffering, sadness, confinement and loss of liberty, but also experiences that seemingly jar with histories of confinement: glee and enjoyment.

For example, when visiting the Galleries, entrance tickets feature randomlydistributed convict numbers corresponding to a particular 'real life' criminal (Figure 4.). Accordingly, visitors are encouraged to follow the story of what becomes 'their' crime. This journey begins with the visitor opening a small hatch that corresponds with their convict number. This reveals a mirror and a sentence (hanging, whipping, burning at the stake, transportation, to name but a few). The mirror creates an illusion where the visitor comes to embody the criminal - with "your own facing looking right back at you" (as we noted in our ethnographic diary, November 2013). This visual technique seeks to enfold the visitor into the history represented, and leads to the co-constitution of carceral atmospheres as visitors engage with the role of prisoner. 


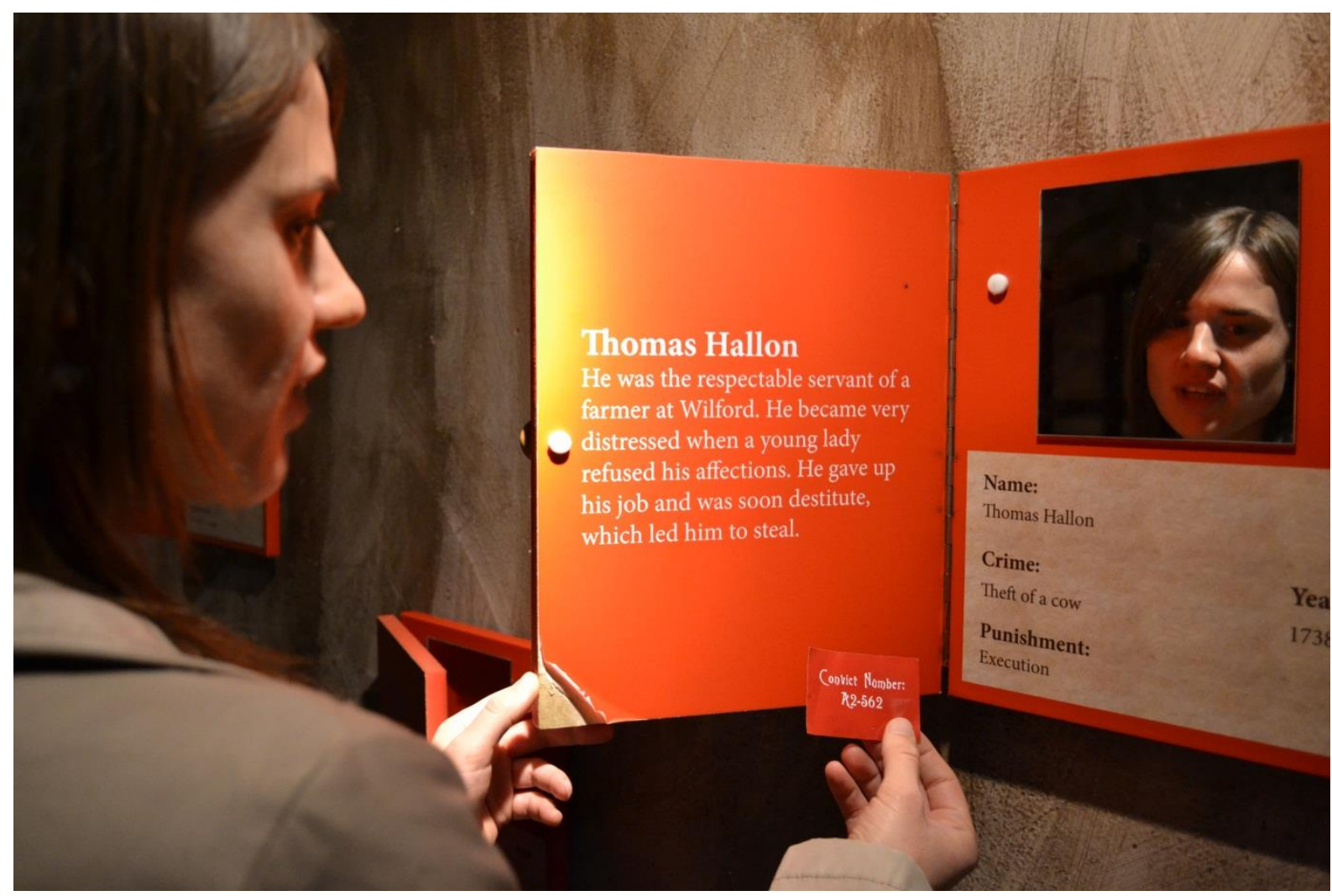

Figure 4.: Discovering your 'real life' convict history, Galleries of Justice, Nottingham, UK. Source: Author's collection.

Indeed, at the Galleries, once the sentence is determined, a spectacle is generated around the sentence that each 'prisoner' receives, co-constituted through playful, yet chilling banter between costumed interpreters and visitors. Indeed, during our participation on these tours, the guides themselves asked members of the group questions such as 'Who's due for a good whipping? Which of you is getting hanged then?' In the exchange between visitors and costumed interpreters, shocking visual cues - the cat, the whip, the shackle-are used to dramatise the representation of penal history. Yet these visual/material cues used in performances engineer atmospheres and sensations of shock and discomfort. A sickening internal feeling and a horror-filled external air is evoked from the "sharp crack and the chips of paint that were removed as the 'turnkey' whipped his cat o' nine tails at the wall" as a 
horrifying realisation dawns of the damage the punishment would have caused to human flesh (Ethnographic Diary, November 2013).

Accordingly then, performance-drawing on the visual/material elements of carceral space-evokes atmospheres that spark affects as the visitor comes into touch with these pervasive 'conditions'. This builds structures of feeling; of haunting, shock, distaste, horror. In engaging with the prison in this way, visitors are physically affected by their experiences; may feel the physical weight of incarcerated atmospheres. Although we might intend to be voyeurs, what we see can often make us tremble or shake, makes us feel cold or sick (Pile, 2010). As one visitor to the Galleries of Justice described,

We then descended to the dungeon and pit areas where another female actor explained the life of prisoners in the past. It was fascinating to note that prisoners could pay for better beds and blankets, otherwise they would get thrown into the pit, which was dark and scary-I didn't dare go inside. We were then left alone to explore the area, I would say that some of the younger kids were upset and uncomfortable in that environment, and I myself wasn't quite sure where to go. Then, a "guv'nor" showed us a replica of the gallows and how hangings were performed. One of the female tourists was visibly disturbed and had to have a breather. (seantyy, Trip Advisor review of visit to Galleries of Justice Nov 2013)

As participant tourists and pseudo-prisoners ourselves we found elements of the performative atmosphere disturbing also. For example, one part of the museum visit involves being locked in a 19th-century cell. On a cold November day, with the wind blowing through the open window bars, an atmosphere was generated through the visual scene (a dark, brick wall cell with little light, no chair, no bed, no straw); the weather conditions of wind, and cold; and the 
performance of the turnkey who slammed the door firmly shut. Here the assemblage of elements-each eliciting a sensory affect-constituted the elusive yet encompassing atmosphere. The aural sensation of the loud, echoing slam of the door, for example, unleashed shock, and then fear. Contained within the cell, claustrophobia then arose; and next, disorientation in the dark. The cold conditions jarred with the hot, nervous sweat and realisation of incarcerated life. As Bjerregaard notes, atmospheres do not create a sense of 'being there' (as we might expect when encountering history at a museum), but generate an intense feeling of 'being here' in the present (2014: 3, original emphasis). Yet the understanding of carceral life created was not one curated through performance, weather conditions or visual experience alone. Neither was it an amalgamation of these things. Rather it was what was generated by this ensemble of 'conditions'(see Waterton and Dittmer, 2014): the sensations that cannot be reduced to technique - atmospheres. An intangible sense arose of what life is to be confined, alongside emergent affects of longing-for warmth, for freedom.

In the spirit of performing our prisoner roles appropriately we were expected to respond to questions and engage with the scenes of incarceration, embroiling us within a created atmosphere of discipline and confinement. Yet, whilst at times atmospheres of carceral life hung uncomfortably in the air through the visual/material elements of the museum and the performances that took cues from these components, atmospheres of morbid enjoyment and glee also arose, seemingly out of place in the site of the prison-a place most associate as lacking joy, freedom and liberty. In the prison museum, the visitor oddly escapes their everyday life to somewhere ordinarily inaccessible; and this leads to a certain kind of enchantment for those who cross the boundary from everyday space to re-created 'penal' space (see McEwan, 2008; Woodyer and Geoghegan, 2012). There is a certain 'delight' for visitors, such as ourselves, in knowing that these performed roles, punishments and the 
prison itself could be later escaped when returning to life 'outside' at the end of the museum visit.

As Huey contends, there is a distance between the visitor and the carceral pasts they encounter at prison museums-'knowing that pain and suffering are being done, but done to another or unknown others - that renders the spectacle both compelling and pleasurable' (2011: 386). As one visitor to the Galleries of Justice wrote, '[t]he stories that they tell are chilling, but beautifully done, and very enjoyable' (wref, Trip Advisor review of visit to Galleries of Justice Jul 2013). Accordingly, a visitor may act as a voyeur of transgression without physically participating in its negativities (Seltzer, 1998: 271; Stephens, 2007). As such, these atmospheres are not mirrors of the prison past itself, but subversions of it; atmospheres perhaps of lightness, in such spaces of 'dark' tourism (Seaton, 1996). As another visitor contemplated,

My own personal view is that a museum dealing with some very grisly, and frankly disturbing, aspects of crime and punishment is NOT suitable for under-10s but this of course never seems to enter the minds of some of those with small kids. Our guide was quite a character (in more ways than one) and did her best to entertain and herd the large group round the various parts of the exhibition. It's probably a fine line to draw, but I did think that the guided tour was a bit too light-hearted and at times tended to trivialise the appalling conditions and suffering of those who passed through the justice system as recently as a couple of hundred years ago. (Gordon2112, Trip Advisor review of visit to Galleries of Justice Dec 2013)

The Galleries of Justice spectacularises life as horrific, with the creation of stereotypical prison characters in the form of the costumed interpreters who provide a 
narrative of prison as a miserable, brutal place. However, even this horror is sensationalised to make it more agreeable to most visitors. The hearty laugh of the turnkey's wife, combined with the (largely) child-friendly narration of prisoners sentenced to execution, contributes to an atmosphere of fun; rather than suffering. As such, horror for entertainment prevails and 'true' horrors are contained. What emerges then, are more sterile or sanitised atmospheres of carceral life that can sometimes lead to a neglect of the more grotesque, or even the more mundane realities of prison life. Atmospheres then are reconstructed and distanced from atmospheres of the past in these places. Indeed in many cases, penal tourist sites become just one more photo opportunity, with people lining up to pose locked up in the pillory or stocks, or enacting the mundane but laborious everyday chores prisoners were assigned to. We noted some of these occasions in our ethnographic diaries:

As visitors to the Galleries of Justice, we took our own mug shots, dressed up in convict uniforms and chalked our prisoner numbers on a slate to hold up while being photographed. In this way, we were encouraged to feel some empathy with those being received to prison in the past, whilst also delighting in this experience of the extraordinary_embodying the convict (Ethnographic diary, November 2013).

Atmospheres then, can be felt differently by each person engaging with the museum space. As MacDonald notes, visiting is a 'situated, differentiated and relatively complex process' that cannot be easily assessed (2007: 152). Accordingly, as Kathleen Stewart contends, atmospheres are 'lived' as the body of the experiencing subject attunes to the affects elicited. As Anderson tells us, 'atmospheres are shared ground from which subjective states and their attendant feelings and emotions emerge' (2009: 78). As such, carceral atmospheres can be affected as recipients engage with them. On the one hand then, some 
atmospheres may be designed and engineered along with the affects that they are intended to induce. Yet on the other hand, the individual subject and collective groups can themselves shape atmospheres; they can contest or reject atmospheres, changing the feelings or remoulding them, as they too affect the places they relate to (Waterton and Dittmer, 2014: 125). Accordingly, whilst atmospheres may appear, and disappear-materialise and fade - they do cohere, albeit momentarily. This is how an atmosphere becomes known as it stabilises, temporarily, for us to feel its affect and in turn grasp its meaning. As such, atmospheres can have characters which repeat, but they also have emergent properties that can change based on its configuration. Every individual carries their own unique history and character that coproduces the atmospheres and the designed techniques they come into contact with. This is also because humans have agency and choice to accept or reject atmospheres; to shape them and mould them through engagement with the sites they permeate and are contained within. Indeed, visitors can even bypass curated carceral atmospheres through the liberty they hold as paying customers (rather than imprisoned convicts). At the Galleries of Justice, the room that visually exhibits the procedure of carrying out the sentence of death by hanging has a warning sign encouraging individuals of nervous disposition to sidestep this particular element of the tour. A visitor can retreat to the warmth of the museum coffee shop for a hot drink. If they like, the guest can simply leave. The fact that visitors from the 'outside' are buying into these prison experiences through choice designates, ultimately, the difference between prisons and penal tourist sites. Visitors can circumnavigate those visual/material cues and performances that build engineered, co-constituted, and even unexpected atmospheres of discomfort and horror, through removing themselves from the 'inside' of these former prisons, back to the 'outside'. 


\section{Conclusions}

In this paper we contend that explorations of museum design and curation-and visitor consumption more generally - are limited if we think through the frames of materiality, performance, sociality and technology alone-as opposed to the more encompassing atmospheres that are manifested through such techniques commonly employed by curators and activated by visitors (see also Bjerregaard, 2014; Waterton and Dittmer, 2014). Whilst an atmosphere is something 'you can't quite put your finger on'-and is impossible to define, here we have attempted to interrogate the qualities of atmospheres that emerge from and are held within the visual/material fabric of former-prison sites that are packaged as museums; and which are produced and co-produced by museum curators and visitors alike.

These penal museums, we propose, evoke carceral atmospheres. We have argued that it is vital to analyse what carceral atmospheres do in such museum settings. Here we have demonstrated how visual/material cues and performances that rely on optical engagement and architectural features, work to engineer atmospheres for visitors that build upon a penal rhetoric of exclusion, desperation, loss of liberty and punishment upon the body. These are constituted through the very nature of spaces that are not ordinarily accessible and which hold a morbid fascination. They generate atmospheres that both seem to encapsulate 'life behind bars' in the past (and present) but those that are based upon assumptions of that life. Prison museums expose those who engage with them to spaces doubly different from the everyday — both a 'pleasurable' leisure space, and concurrently a 'disturbing' prison space. The atmospheres generated, curated, co-constituted and emerging unexpectedly, vary from those we might expect-based on previous perceptions of the prison, built up in media constructions and our imaginations (of violence, horror, and a stripping of liberty) - to atmospheres that seem to jar with such visual/material engagement (atmospheres of enjoyment and pleasure). One place doesn't have one atmosphere then. Atmospheres can be 
durable. Places may have sustained atmospheres that linger in the air so that we characterise a specific site with a specific atmosphere (all dungeons are dark and frightening for example). But atmospheres can also shift and change. A home space can be one of joy, but also through events, it can be transformed into one of sadness. The museum is a container of atmosphere, but it is not 'air-tight': the atmosphere will change. It will seep out as people leave and take something of it with them, and it will change again as other visitors enter in their place. Accordingly, these are spaces that scholars must explore to better understand how prison is understood and engaged with in the present.

Arguably though, thinking with atmospheres is not merely useful for further exploring the workings of museums in conveying history or the histories of prisons more specifically. Atmospheric attunements (Stewart, 2011) can, and should, be enlivened when thinking of the visual/material workings of architecture more generally, and present day penal architecture more specifically. Studies of prison architecture have been inherently visual in approach, without considering how visual/material communication evokes affective atmospheres for those who engage with such spaces. For example, in their early- $18^{\text {th }}$-century existence, prisons exhibited a threatening exterior, which was often decorated by visually intimidating gargoyles or figures pictured behind bars. This meant that although the bricks would hide what was taking place within, the public could still be reminded of the sombre nature of the building and the detrimental aspects of committing crimes (Pratt, 2002: 37). Analysis of such architecture can be taken one step further if we consider how such visual/material design generates an affective atmosphere of fear —of imprisonment—for those on the outside who came into touch with the visual/material scene of the prison.

Scholars in carceral geography and criminology are beginning to explore these affective links between carceral spaces — their architecture, design, and technology — and the populations they contain (see Moran and Jewkes, forthcoming). Unlike the museum visitor, 
long-term prisoners cannot so easily walk away from such environments. They rarely have the ability to choose different surroundings if they feel uncomfortable. If the prison

museum - its visual/material form and performative elements designed around this - can create an atmosphere, carceral geographers might be interested to explore how atmospheres are evoked by prison itself and the lingering impact it may have upon prisoners both within and once they leave the physical place. This should remain cognisant in conversations between prison authorities, offender managers and prison designers surrounding the potential impact of the visual/material surroundings upon offender management and rehabilitation. It is here that an interrogation of carceral atmospheres might have even more 'affect'.

\section{Notes}

${ }^{1}$ When approaching the study of 'what we see' and 'how we see it', academics have typically sought to unpack the intangible meanings rather than the material realities, embedded in visual culture. In this paper we follow the interventions of Gillian Rose and Divya ToliaKelly (2012) to interrogate the manifold and complex 'visual/material' connections between physical forms and what is seen and what is hidden in prison museums.

\section{References}

Adey P (2008). Airports, mobility and the calculative architecture of affective control. Geoforum 39(1): 438-451.

Adey P (2013) Air/atmospheres of the megacity. Theory, Culture \& Society 30(7): 291-308. Anderson B (2006) Becoming and being hopeful: towards a theory of affect. Environment and planning D 24(5): 733-752.

Anderson B (2009) Affective atmospheres. Emotion, Space and Society 2(2) 77-81. 
Ash J (2013) Rethinking affective atmospheres: technology, perturbation and space times of the non-human. Geoforum 49: 20-28.

Bagnall G (2003) Performance and performativity at heritage sites. Museum and Society, 1(2): 87-103.

Baker B (2014) Crime and Punishment: Discover Nottingham's Horrible History. Peterborough: Jarrod Publishing.

Bjerregaard P (2014) Dissolving objects: Museums, atmosphere and the creation of presence. Emotion, Space and Society. Epub ahead of print 3 June 2014. DOI: 10.1016/j.emospa.2014.05.002.

Broeckmann A (1995) A Visual Economy of Individuals: The Use of Portrait Photography in the Nineteenth-Century Human Sciences. PhD Thesis, University of East Anglia, UK.

Bruggeman SC (2012) Reforming the carceral past: Eastern State Penitentiary and the challenge of the twenty-first-century prison museum. Radical History Review 113: 171-186.

Butz D and Besio K (2009) Autoethnography. Geography Compass, 3: 1660-1674.

Ciofi L and Bannon LJ (2007) Designing hybrid places: merging interaction design, ubiquitous technologies and geographies of the museum space. CoDesign: International Journal of CoCreation in Design and the Arts 3(3): 159-180.

Crang M (1994) Spacing times, telling times and narrating the past. Time Society 3(1): 29-45. Crang M (2003) On display: the poetics, politics and interpretation of exhibitions. In: Ogborn M, Blunt A, Gruffudd P, Pinder D, and May J (eds) Cultural Geography in Practice. London: Arnold, pp. 255-268.

Crang M and Cook I (2007) Doing Ethnographies. London: Sage.

DeSilvey C (2006) Observed Decay: Telling Stories with Mutable Things. Journal of Material Culture 11(3): 318- 338. 
Eastern State Penitentiary (2013) Eastern State Penitentiary Visitor Pamphlet. Philadelphia, PA: Eastern State Penitentiary.

Eastern State Penitentiary (2014) Plan your visit. Available at: http://www.easternstate.org/ (accessed 12 October 2014).

Edensor T (2007) Sensing the ruin. The Senses and Society 2(2): 217-232.

Edensor T (2008) Mundane hauntings: commuting through the phantasmagoric working-class spaces of Manchester, England. Cultural Geographies 15(3): 313-333.

Garrett BL(2011) Assaying history: creating temporal junctions through urban exploration. Environment and Planning D: Society and Space 29(6): 1048-1067.

Geoghegan H (2010) Museum Geography: Exploring Museums, Collections and Museum Practice in the UK. Geography Compass 4(10): 1462-1476

Gordon AF (2008) Ghostly Matters: Haunting and the Sociological Imagination Minneapolis, MN; London: University of Minnesota Press.

Hooper-Greenhill E (1992) Museums and the shaping of knowledge. London: Routledge.

Hoskins G (2004) A place to remember: scaling the walls of Angel Island immigration station. Journal of Historical Geography 30(4): 685-700.

Hoskins G(2007) Materialising memory at Angel Island Immigration Station, San Francisco. Environment and Planning A 39(2): 437-455.

Howes D (2014) Introduction to sensory museology. The Senses and Society 9(3): 259-267.

Huey L (2011) Crime behind the glass: exploring the sublime in crime at The Vienna Kriminalmuseum. Theoretical Criminology 15(4): 381-399.

Johnson NC (1999a) The spectacle of memory: Ireland's remembrance of the Great War, 1919. Journal of Historical Geography 25(1): 36-56.

Johnson NC (1999b) Framing the past: time, space and the politics of heritage tourism in Ireland. Political Geography 18(2): 187-207. 
Johnston NB, Finkel K and Cohen JA (1994) (eds) Eastern State Penitentiary: Crucible of Good Intentions. Philadelphia, PA: Philadelphia Museum of Art for the Eastern State Penitentiary Task Force of the Preservation Coalition of Greater Philadelphia.

Karp I and Lavine SD (1990) eds. Exhibiting cultures: the poetics and politics of museum display. Washington, DC: Smithsonian Institution.

Langer $\mathrm{R}$ and Beckman SC (2005) Sensitive research topics: netnography revisited. Qualitative Market Research: An International Journal 8(2): 189-203.

MacCannell D (1973) Staged authenticity: Arrangements of social space in tourist settings. American journal of Sociology 79(3): 589-603.

MacCannell D (1999) The Tourist: A New Theory of the Leisure Class. Berkeley, CA: University of California Press.

MacDonald S (2007) Interconnecting: museum visiting and exhibition design. CoDesign: International Journal of CoCreation in Design and the Arts 3(1): 149-162

Magnani L (1990) America's First Penitentiary: A 200 Year Old Failure. San Francisco: American Friends Society Committee.

Mayerfeld-Bell M (1997) The ghosts of place. Theory and society 26(6): 813-836.

McCormack DP (2008) Engineering affective atmospheres on the moving geographies of the 1897 Andrée expedition. Cultural Geographies 15(4): 413-430.

McEwan C (2008) A very modern ghost: postcolonialism and the politics of enchantment. Environment and Planning D: Society and Space 26: 29-46

Moran D and Jewkes $\mathrm{Y}$ (forthcoming) Linking the carceral and the punitive state: Researching prison architecture, design, technology and the lived experience of carceral space. Annales de Géographie. 
Morrison W (2004) Lombroso and the birth of criminological positivism: scientific mastery or cultural artifice? In: Ferrell J, Hayward K, Morrison W and Presdee, M (eds) Cultural Criminology Unleashed., London: The Glasshouse Press, pp. 67-80.

Paechter C (2013) Researching sensitive issues online: implications of a hybrid insider/outsider position in a retrospective ethnographic study. Qualitative Research 13(1): 71-86.

Pile S (2010) Emotions and affect in recent human geography. Transactions of the Institute of British Geographers 35(1): 5-20.

Pratt J (2002) Punishment and Civilization: Penal Tolerance and Intolerance in Modern Society. London: Sage.

Rose G and Tolia-Kelly D (2012) Visuality/Materiality: Images, Objects, Practices. Farnham: Ashgate.

Seaton, A (1996) Guided by the dark: from thanatopsis to thanatourism. Journal of Heritage Studies 2(4): 234-244.

Seltzer M (1998) Serial Killers: Death and Life in America's Wound Culture. New York, NY: Routledge.

Stephens J (2007) From guesthouse to Guantánamo Bay: global tourism and the case of David Hicks. Tourism Culture \& Communication 7(2): 149-156.

Stewart K (2011) Atmospheric attunements. Environment and Planning D: Society and Space 29(3): 445-453.

Strange C and Kempa M (2003) Shades of dark tourism: Alcatraz and Robben Island. Annals of Tourism Research 30(2): 386-405.

Turner J (2013) Edge and Interface: Boundary Traffic Between Prison and Society. PhD Thesis, Aberystwyth University, UK. 
Walby K and Piche J (2011) The polysemy of punishment memorialization: dark tourism and Ontario's penal history museums. Punishment \& Society-International Journal of Penology 13(4): 451-472.

Waterton E and Dittmer J (2014) The museum as assemblage: bringing forth affect at the Australian War Memorial. Museum Management and Curatorship 29(2): 122-139.

Woodyer T and Geoghegan H (2012) (Re)enchanting geography? The nature of being critical and the character of critique in human geography. Progress in Human Geography 37(2): 195214. 